\title{
Woodpeckers in Western Norway: the White-backed Woodpecker is still the most common species
}

\author{
Magne Sætersdal ${ }^{*}$, Ivar Gjerde ${ }^{1} \&$ Einar Heegaard $^{2}$ \\ ${ }^{1}$ Norwegian Institute of Bioeconomy Research, Thormølensgate 55, 5006 Bergen, Norway \\ ${ }^{2}$ County Governor of Rogaland, Climate and environment, Statens Hus, Lagårdsveien 44, Postboks 59, 4001 Stavanger, Norway \\ *Corresponding: magne.setersdal@nibio.no
}

\begin{abstract}
The pine-dominated forests of Western Norway have been found to harbour viable populations of woodpeckers, including the highly specialized White-backed Woodpecker Dendrocopos leucotos. The aim of this study was to investigate to what extent there were any changes in frequencies of woodpeckers, in particular the White-backed Woodpecker and the Grey-headed Woodpecker Picus canus, by resurveying 60 plots (each $1 \mathrm{~km}^{2}$ ) originally surveyed during 1994/1995. The resurvey was performed in 2013/2014. The White-backed Woodpecker was found to be the most common woodpecker species in both time periods. The Grey-headed Woodpecker was found to have a statistically significant decline from $27 \%$ of the 60 plots in $1994 / 95$ to only $12 \%$ in 2013/14. The other four species all increased in frequency; although none of those increased frequencies were found to be statistically significant. We discuss possible explanations to why pine forests in Western Norway constitute a valuable habitat for the White-backed Woodpecker at the same time as it has drastically declined in other parts of Norway and Western Europe. In general, the reduced frequency of Grey-headed Woodpecker is not fully understood, although we suggest that cold winters during the years prior to the surveys in 2013/14 may be an important factor.
\end{abstract}

Keywords: Western Norway, woodpeckers, pine-dominated forests, population densities

\section{INTRODUCTION}

Forest bird species have recently been found to show highly varying population trends in Europe (Lehikoinen \& Virkkala 2018). In a European perspective declining trends are more pronounced in northern parts. Combined population trends for 26 forest species in Norway, Sweden and Finland show a decline of approximately 25\% during 1982-2012 (Lehikoinen \& Virkkala 2018). In particular, resident species and species associated with old-growth forests show clear declines in Finland during recent decades (Lehikoinen \& Virkkala 2018, Fraixedas et al. 2015).

In Sweden and Finland, the populations of the deadwood-dependent White-backed Woodpecker Dendrocopos leucotos have been drastically reduced in numbers during the last century (Carlson 2000, Roberge et al. 2008a, Stighäll 2015). However, in Finland the population has increased by $300-400 \%$ from a historic low population size in the 1980-1990s (Lehikoinen et al. 2011). Although the White-backed Woodpecker is extinct in large parts of Eastern Norway the species has been found to have viable populations in southern and western parts of Norway (Stenberg 2004, Gjerde et al. 2005). In this area the population size has been estimated to be approximately 1700 pairs (Stenberg 2004). However, no population data on this species from the last 20 years have been published. It is therefore of interest to present new data on the frequency of White-backed Woodpecker and other woodpeckers from recent years to compare with earlier data.

In Northern Europe, woodpeckers have been proposed to be indicator species of forest "naturalness" (Roberge et al. 2008a). Woodpecker abundances are found to vary with density of dead wood, land use history, and forest harvesting levels (Mikusinski et al. 2001, Gjerde et al. 2005, Roberge \& Angelstam 2006, Roberge et al. 2008a). Furthermore, nestingholes excavated by woodpeckers constitute a keystone resource for many secondary hole-nesting bird and bat species (Remm \& Lõhmus 2011; Michaelsen 2016; Andersson et al. 2018). Finally, the White-backed Woodpecker has been suggested as an important umbrella species for inconspicuous dead-wood living organisms, such as many insects and fungi (Roberge et al. 2008b).

Generally, forest reserves and woodland key habitats are too small to ensure populations of the area-demanding woodpecker species (Haavik \& Dale 2012). Management of these species is therefore to a large extent dependent on a sustainable forestry including maintaining dead wood and deciduous trees in sufficient amounts at landscape scale.

The aim of this study was to investigate whether there were any changes in the frequencies of woodpecker species in Western Norway between 1994/1995 and 2013/2014. Of particular interest was 
the frequency of the White-backed Woodpecker and the Grey-headed Woodpecker, which were found to be the two most common woodpecker species in the 1990s (Gjerde et al. 2005). We did this by resurveying woodpecker species in 60 forests dominated by Scots Pine Pinus sylvestris (each study plot of 100 ha) that were surveyed in 1994/1995 (Gjerde et al. 2005). We discuss the results of this study in light of the general development of key forest structures, such as dead wood and deciduous trees, in Western Norway.

\section{MATERIAL AND METHODS}

\section{Study area}

The pine-dominated forests of Western Norway represent the western limit of the boreal forest zone of Eurasia. Western Norway is characterized by a pronounced oceanic climate. This climate separates these pine forests from the more continental pine forests of Eastern Norway and beyond. The oceanic climate is also linked to a distinct Atlantic biogeographic element of species, in particular within lichens and bryophytes (Moen 1999). The landscapes of Western Norway are characterised by mountains and steep slopes along the

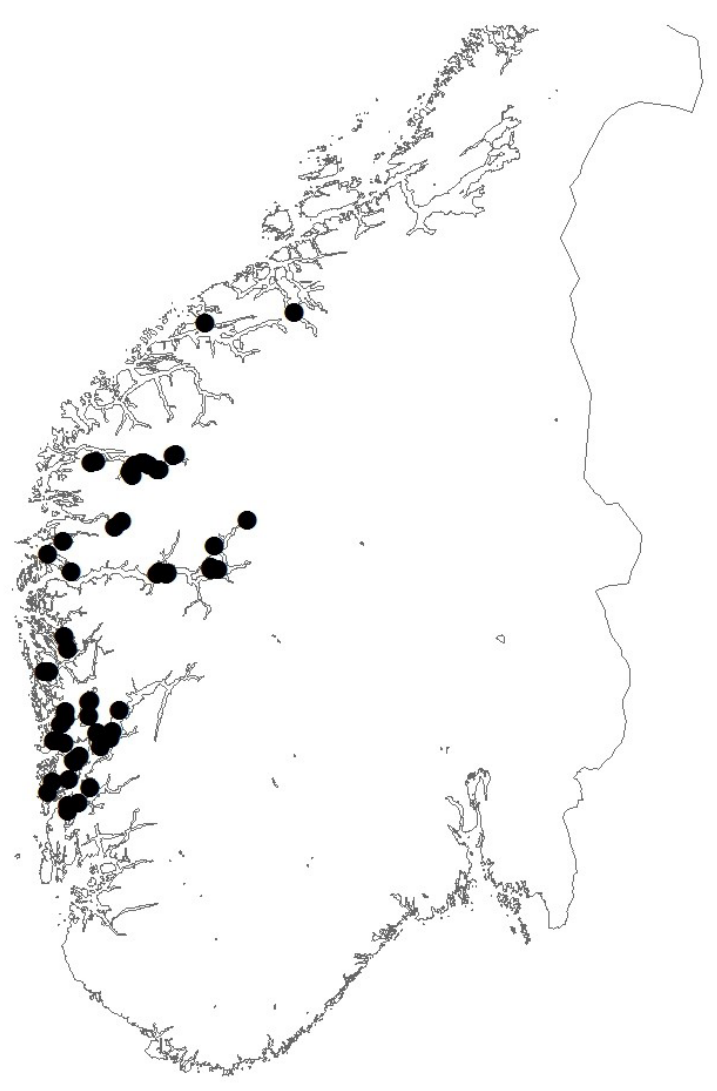

Figure 1. The position of the 60 investigated plots from pinedominated forests in western Norway that were included in the study. fjords. Because natural colonization by Norway Spruce Picea abies has only reached Western Norway in small areas in the inner and northern parts, pine forests are found on soils that are usually occupied by spruce forests in other parts of Norway. However, 10-15\% of the pine forests in Western Norway have been converted to spruce plantations (Øyen et al. 2006). In total, pine-dominated forests constitute $32 \%$ of the area of productive forest within the four counties of Western Norway (Granhus et al. 2012). Spruce forest (both plantations (1.7 million daa) and natural colonisation (50 000 daa (Øyen 2007)) constitutes $16.5 \%$, broad-leaved deciduous forest $2.7 \%$, and other deciduous forest (mainly birch Betula pubescens forest) constitutes $45.4 \%$ (Granhus et al. 2012).

\section{Woodpecker survey}

This study is a resurvey of 60 of the original 100 circular sample plots (100 ha each) in pine-dominated forest in Western Norway (Figure 1) included in Gjerde et al. (2005). The original plots were selected as a stratified sample based on the proportion of spruce plantations, with 20 random samples in each of the categories < $10 \%, 11-30 \%, 31-50 \%, 51-70 \%$, and $>70 \%$ spruce plantations in pine forests. Because the probability of presence of woodpecker species in plots with more that $50 \%$ spruce plantations turned out to be low (Gjerde et al. 2005), we excluded the 40 plots with proportions exceeding that level. As a result, the mean proportion of spruce plantations (ca 20\%) in the remaining plots was more representative of the whole study area. Because of very low levels of spruce planting in the region during the last 20 years (Tomter \& Dalen 2018) the cover of spruce in the plots had not changed significantly from the 1990 s to $2013 / 2014$. Plots were originally selected from areas below $400 \mathrm{~m}$ of elevation and with a forest site index exceeding $5 \mathrm{~m}^{3} /$ ha/year.

Each plot was visited once in each of the time periods 1994/1995 and 2013/2014, and during the period March 20th to June 20th. Care was taken to ensure that the resampling protocol was similar to the sampling in 1994/95. In each plot, presence of woodpeckers was surveyed for 3-4 hours between 05.00 and 09.00 by systematically walking through the plot area, and by playing a tape with woodpecker sounds for 10 minutes at four preselected points with a minimum distance of $400 \mathrm{~m}$ from each other. The same four points were visited in 2013/14. In addition, all woodpeckers heard or seen while moving between the four preselected points were also registered. Hence, the methodology resembles the TOV-E methodology used in bird monitoring in Norway (Program for terrestrisk naturovervåking 2019) in that it is a combination of point censuses and line transects. The important point, however, is that the same methodology was used between the two time- 


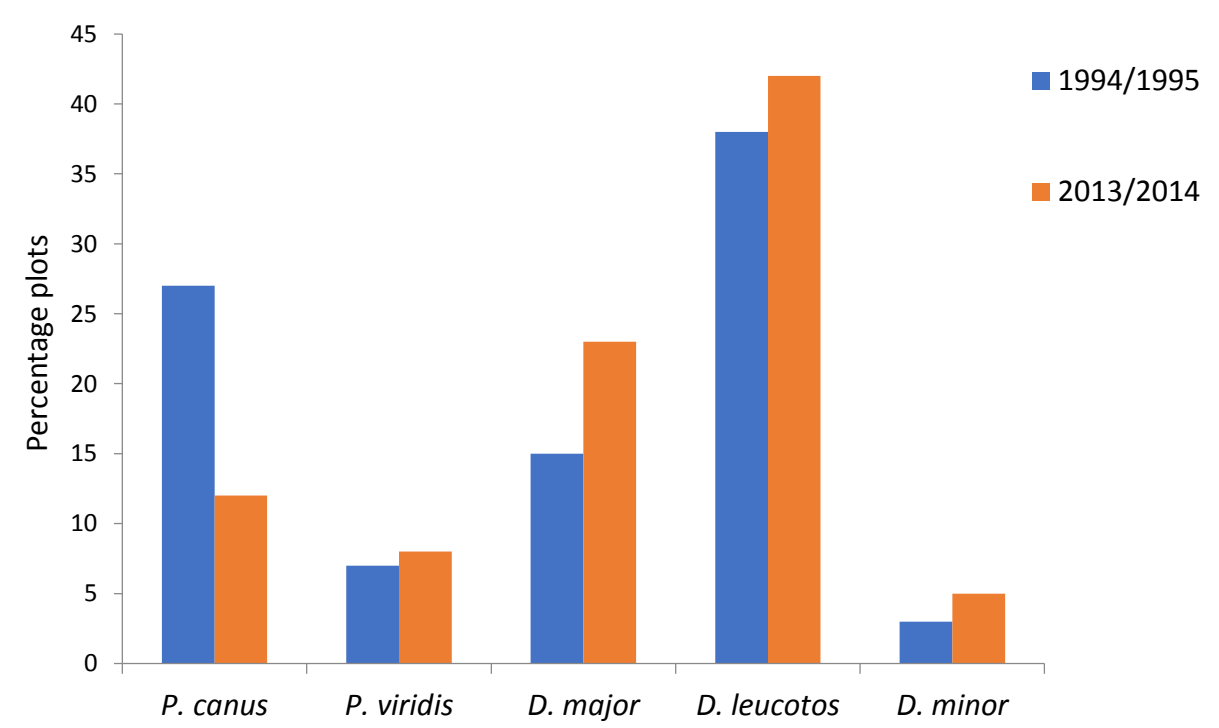

Figure 2. Percentage plots (of the 60 plots) with observations of the woodpecker species in 1994/1995 and 2013/2014.

periods to investigate whether there are any differences in frequencies, not to obtain absolute densities of the woodpecker species. We consider the method to be well suited to compare frequencies between years. To ensure that the methodology was comparable between 1994/95 and 2013/14 the very same tape and tape recorders were used during the resampling. The tape contained recordings of species-specific woodpecker drummings/calls lasting 1 minute interspersed with a 1-minute period of silence. The following regularly occurring species in western Norway were included in the playback track: Grey-headed Woodpecker Picus canus, Green Woodpecker Picus viridis, Great Spotted Woodpecker Dendrocopos major, Whitebacked Woodpecker, and Lesser Spotted Woodpecker Dryobates minor. The Wryneck Jynx torquilla was not included in the survey because it is a migratory species that does not arrive in Norway before early May. The position and movements of all target woodpeckers heard or seen within the plot were marked on a map, and the minimum number of observed individuals of each species was registered. See Gjerde et al. (2005) for further details.

The White-backed Woodpecker is known to respond most effectively to playback during the prelaying phase. During the incubation period the species is more secretive. Thus, prior to the resurvey we checked the data from 1994/1995 to see if there were consistent differences in observed frequencies of the White-backed Woodpecker between the periods March/ April (27.3\%), May (27.8\%), and June (25\%). No statistically significant differences in plot frequencies were found between the periods. (chi-square tests: 1 ) March/April versus May: $\chi^{2}=0.002$, not significant; 2) March/April versus June: $\chi^{2}=0.03$, not significant; 3) May versus June: $\chi^{2}=0.03$, not significant).
Analyses

Tests of changes in probability of occurrence of the individual species were performed by Bayesian hierarchical logistic regression with survey periods as fixed effect and plots as latent contribution pairing the observations. We used Integrated Nested Laplace Approximations to estimate the posterior distribution of temporal difference for the bird species (Rue et al. 2009). In addition, we assessed the probability of a plot being occupied at both surveys and whether it deviated from expected under temporal independence. The independence background was generated by permutating the species-specific observation during the second survey.

\section{RESULTS}

As can be seen from Figure 2, the White-backed Woodpecker was the most common woodpecker species in the pine forests of Western Norway in both time periods. The White-backed Woodpecker was found in 23 plots (38\%) in 1994/95. Fifteen $(65 \%)$ of these 23 plots also contained White-backed Woodpecker in $2013 / 14$. In total the White-backed Woodpecker was found in $25(42 \%)$ plots in 2013/14. However, the increased frequency was not statistically significant (Figure 3). The second most abundant woodpecker species in 1994/95 was the Grey-headed Woodpecker. However, in 2013/14 the Great Spotted Woodpecker was the second most abundant species, and twice as abundant as the Grey-headed Woodpecker. Green Woodpecker and Lesser Spotted Woodpecker were the least common species in both time periods.

The Grey-headed Woodpecker declined from being 


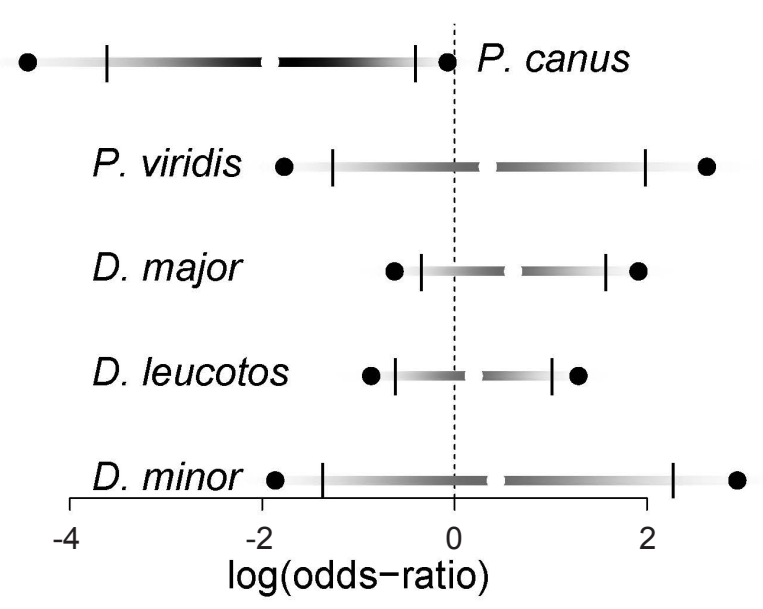

Figure 3. The coefficient of change in probability of occurrence for the individual species of woodpeckers based on a Bayesian hierarchical logistic regression with time periods (1990s versus 2010s) as fixed effect and identity of the plots as latent contribution pairing the observations. The horizontal bars represent the posterior distribution of the parameters, with $95 \%$ and $99 \%$ credibility interval indicated by the vertical small bars and filled dots, respectively. If the horizontal bars do not include zero the change in probability is deemed significant.

present in $27 \%$ of the 60 plots in $1994 / 95$ to only $12 \%$ in 2013/14. This decline in Grey-headed Woodpecker was found to be statistically significant (Figure 3). The other four species all increased in frequency. However, none of those increased frequencies were found to be statistically significant (Figure 3).

For the White-backed Woodpecker, the tendency to be found in the same plots at the two surveys did not deviate significantly from the expectation under independent distribution of occupancy, $p=0.53$. For Green Woodpecker, the probability of occurring in the same plots was significantly greater than expected, $p=0.03$. The same was found for both Grey-headed Woodpecker and Great Spotted Woodpecker, p-values $=0.014$ and 0.004, respectively. For the Lesser Spotted Woodpecker there were no observations in the same plots at the different surveys.

\section{DISCUSSION}

The woodpecker species in this study represent three different feeding strategies (Lõhmus et al. 2016). First, there are two dead-wood dependent species, the White-backed Woodpecker and the Lesser Spotted Woodpecker. Second, there are two ground feeding species, namely the Green Woodpecker and the Grey-headed Woodpecker. Third, there is one generalist species, the Great Spotted Woodpecker. Of these species only the ground-feeding Grey-headed Woodpecker showed significant change in frequency from $1993 / 94$ to $2013 / 14$. In the following we will concentrate the discussion on the White-backed Woodpecker and the Grey-headed Woodpecker. Both species have large populations in Western Norway compared to other parts of Norway. In addition, they both have been red-listed in Norway. Thus, the region may be seen as holding a special management responsibility for these two species.

\section{White-backed Woodpecker}

We found the White-backed Woodpecker to be the most common woodpecker species in the pine-dominated forests of Western Norway in both periods (Figure 2). This in itself is a striking result. It is well documented from other parts of Europe that the White-backed Woodpecker is strongly associated with deciduous forests (Aulen 1988, Virkkala et al. 1993, Carlson 2000, Angelstam et al. 2002, Czeszczewik \& Walankiewicsz 2006). However, studies from Western Norway have shown that White-backed Woodpecker is found in both deciduous forests and pine forests (Stenberg \& Hogstad 1992, Gjerde et al. 2005). Stenberg \& Hogstad (1992) found the densities to be higher in deciduous forests than in pine forests. Furthermore, Gjerde et al. (2005) found that the White-backed Woodpecker preferred pine forest plots with a high proportion of deciduous trees. Stenberg \& Hogstad (2004) found that grey alder Alnus incana and aspen Populus tremula were preferred tree species for both sexes, and sallow Salix caprea for females, when feeding on insects in dead and living trees. The predominant prey insects were found to be Cerambycidae beetle larvae (Stenberg \& Hogstad 1995). The most common prey species was Oxymirus cursor.

We suggest that there are at least four possible explanations why pine-dominated forests constitute a valuable habitat for the White-backed Woodpecker in Western Norway. First, the possibility for intensive forestry is limited due to the rugged topography. Approximately $31 \%$ of the productive forest area in Western Norway is classified as cable yarding terrain (Granhus et al. 2012). The net profit from cable yarding operations is very low. Hence, a large proportion of the forests of Western Norway have not been harvested for at least half a century. Second, unlike in most of the boreal region of Northern Europe the pine forests of Western Norway are also found on richer soils. A richer soil may contribute to a higher amount of dead wood per area in forests (Sippola et al. 1998). Third, an oceanic climate with mild winters is found to be beneficial to the physical conditions of female Whitebacked Woodpeckers in Western Norway during prelaying and egg-laying periods in the spring (Hogstad \& Stenberg 1997, Hogstad \& Stenberg 2005). Physical condition is important for breeding success, and 
females in good physical condition have larger clutch sizes and have fledglings with a higher body-mass than females in poor physical condition (Hogstad \& Stenberg 2005). Fourth, in continental areas pine snags (standing dead trees) are typically hard and dry compared to the pine snags in coastal areas (pers. obs.). An oceanic climate with mild winters may contribute to a different insect fauna in pine snags compared to pine snags in more continental areas. It is also possible that the soft snags in coastal areas make it easier for the birds to excavate beetle larvae from the wood. This may in turn be important for the physical condition of females in the spring (Hogstad \& Stenberg 1994, Hogstad \& Stenberg 2005).

The White-backed Woodpecker is adapted to feed on insect larvae in dead wood, mainly beetle and moth larvae (Aulén 1988, Stenberg \& Hogstad 1995). It is therefore dependent upon a high level of dead wood (e.g. Stenberg \& Stokke 2003, Czeszczewik 2009, Czeszczewik, et al. 2013). Interestingly, the amount of dead wood in Western Norway (Rogaland, Hordaland, Sogn \& Fjordane, and Møre \& Romsdal) has increased from $7.0 \mathrm{~m}^{3} /$ ha in the $1990 \mathrm{~s}$ to $12.9 \mathrm{~m}^{3} /$ ha in the $2010 \mathrm{~s}$, an increase of $84 \%$ (Storaunet \& Rolstad 2015). The White-backed Woodpecker prefers to feed on insects in standing dead trees (Aulén 1988, Gjerde et al. 1992, Hogstad \& Stenberg 1994, Gjerde et al. 2005). It is therefore of interest to look at the trends in snag densities during the period of this study. Again, the data from the Norwegian National Forest Inventory unequivocally indicate that the amount of snags has increased during the same 20 year period. In the counties Hordaland and Sogn \& Fjordane the increase in snag density is $111 \%$ and $70 \%$, respectively (Storaunet \& Rolstad 2015). However, the frequency of the Whitebacked Woodpecker did not increase from the first to the second inventory. One possible explanation may be that the volume increase in dead wood does not translate into a relevant resource availability measure for the species. For instance, concentrations of snags $(\geq$ 8 standing dead trees per $0.2 \mathrm{ha}$ ) as they are defined in the Norwegian woodland key habitat method (Gjerde et al. 2007) have not increased in Western Norway from 2005 to 2015 (Gjerde \& Sætersdal 2017). This suggests that the increased amount of snags has primarily resulted in a more even distribution. As the White-backed Woodpecker is dependent on high densities of snags within their breeding territories it is possible that the lack of increase in concentrations of snags may explain the lack of increased frequency from the 1990s to the 2010s. Further studies are needed to test this relationship.

In this study, we did not find a higher frequency of White-backed Woodpecker in 2013/2014 within pinedominated plots compared to 1994/1995. Nevertheless, we hypothesise that the total population size of Whitebacked Woodpecker in Western Norway has increased during recent decades. The reason for this is found in the forest history of Western Norway. According to the National Forest Inventory the total area of forests in Western Norway has doubled during the last 100 years because of extensive afforestation of former semi-natural grasslands (Andreassen et al. 2013). Most of this area has become deciduous forests. In recent decades, these new forests have matured and been subject to self-thinning, resulting in deciduous forests with relatively high densities of dead trees. However, these new deciduous forests were not included in this study which concentrated on pine-dominated forests. Further studies are needed to evaluate the frequency of White-backed Woodpecker in these deciduous forests.

Surprisingly, we found that the dead-wood dependent White-backed Woodpecker, in contrast to the other species, did not tend to be found in the same plots at the two surveys. Again, we suggest that the explanation to this result may be found in the forest history of Western Norway. Around the middle of the twentieth century, dimension felling was replaced by modern forestry practices, including clear-felling of whole stands and subsequent afforestation with seeding or planting. In Western Norway, clear-felling has primarily been conducted on areas that have been transformed to spruce plantations $(16.5 \%$ of productive forest area) (Granhus et al. 2012). This implies that more than $80 \%$ of the productive forest area has not yet been harvested by clear-felling. Time since last logging in pine forests of Western Norway typically varies from 50 to 150 years. This variation in time since last logging implies that different stands typically differ in their dominating age of trees. This in turn implies that different forest stands are maturing and subject to selfthinning at different times. The period of self-thinning of pine trees represents a period of high concentration of standing dead wood (a pulse in standing dead wood). Other factors, such as bark-beetle outbreaks, droughts, forest fires and storm-felling, may also create patches of high concentrations of standing dead trees that are utilized by the White-backed Woodpecker. The important point is that such concentrations do not last for more than a few decades (Privetivy et al. 2018). Hence, the White-backed Woodpecker may be found to respond to a dead-wood pulse at a site by establishing a nesting territory. As new pulses in snag availability are formed in other parts of the landscape the territory is moved to these parts.

\section{Grey-headed Woodpecker}

Gjerde et al. (2005) found that the Grey-headed Woodpecker was more frequent in coastal areas in Western Norway, compared to more continental parts along the fjords in inner parts of Western Norway. These coastal areas are characterized by mild winters 
and few days with snow cover. Lõhmus et al. (2016) found that the population density of the Grey-headed Woodpecker was vulnerable to prolonged periods of cold winters and deep snow. A period of low abundance was documented following three snowrich winters in 2009/2010, 2010/2011, and 2011/2012 (Lõhmus et al. 2016). In fact, the same period was a cold period in Western Norway as well. The winter of $2009 / 2010$ was exceptional in that the ground along the coast was continually covered by snow for a period of three months. In addition, the winters of 2011 and 2013 were also cold winters in Western Norway. We suggest that these cold winters may at least partly explain the reduction in the Grey-headed Woodpecker population found in this study. Similar results have been reported from Finland (Saari \& Mikusinski 1996). Rolstad \& Rolstad (1995) found that the availability of winter food was a critical factor. When the ground was snowfree, the Grey-headed Woodpecker preyed almost exclusively upon ant colonies on the ground. When the snow covered the ground in winter, the birds were feeding on bark-dwelling insects in old pine and dead trees. The change in diet in winter was accompanied by a 100 times enlargement in home range size, increasing from $0.5-1 \mathrm{~km}^{2}$ in summer to $45-54 \mathrm{~km}^{2}$ in winter (Rolstad \& Rolstad 1995). Winter home ranges of up to $20 \mathrm{~km}^{2}$ are reported from Sweden (Edenius et al. 1999). Based on this, we hypothesise that the population in Western Norway is vulnerable to cold winters. In winters with few days of snow-cover in the coastal parts, the birds can feed on ants on the ground within a limited area. However, when snow-cover lasts for prolonged periods in cold winters, the birds must enlarge their home ranges and winter survival may be reduced as a result of limited availability of food. Consequently, breeding densities are reduced.

The Green Woodpecker is also an ant feeder. This species did not show any reduction in frequency in this study, as opposed to the Grey-headed Woodpecker. One might expect the same trend for both species. However, Gjerde et al. (2005) did not find that the Green Woodpecker was significantly more frequent along the coastline of Western Norway, compared to areas along the fjords in inner parts of Western Norway, as was the Grey-headed Woodpecker (Gjerde et al. 2005). One possible explanation for this may be that the winter feeding diet and -strategy is different between the two species. Rolstad et al. (2000) found that the Green Woodpecker in eastern Norway during winter fed exclusively on mound-building Formica rufa ants in older forests. Probably these ant-mounds are more easily detected under snow compared to the ants fed by Grey-headed Woodpecker (mainly Serviformicagroup). It may therefore be reasonable to assume that the Green Woodpecker is better adapted to snow-rich conditions than the Grey-headed Woodpecker.

It was also found by Gjerde et al. (2005) that the
Grey-headed Woodpecker strongly preferred areas with large aspen trees for breeding. However, according to the National Forest Inventory the volume of large aspen trees (more than $30 \mathrm{~cm}$ diameter at breast height) in Western Norway has more than doubled during the period of this study (A. Granhus pers. comm.). It is therefore not likely that the reduction in this species can be explained by any reduction in nesting trees.

Making inferences about population trends based on two surveys many years apart is problematic (e.g. Byrkjedal \& Kålås 2012). Repeated surveys over many years would be preferable. However, we found significant changing frequencies in only one species. This indicates that the forests of Western Norway are still holding viable populations of most woodpeckers, including the White-backed Woodpecker. More studies are needed to understand the decline of the Greyheaded Woodpecker in this study. The present project on woodpeckers in Western Norway is continuing surveys to document potential variation between years. Furthermore, the new surveys include an equal number of plots from deciduous forests in order to compare densities between major forest types as well as being able to present estimates of total population sizes in Western Norway.

Acknowledgements. We are grateful to the County Governor of Hordaland, the County Governor of Sogn \& Fjordane, and Nibio for financial support of this study. We are also grateful to two anonymous referees for valuable comments.

\section{REFERENCES}

Andersson, J., Domingo Gomez, E., Michon, S. \& Roberge, J.-M. 2018. Tree cavity densities and characteristics in managed and unmanaged Swedish boreal forest. Scandinavian Journal of Forest Research 33: 233-244.

Andreassen, K., Eriksen, R., Tomter, S. \& Granhus, A. 2013. Statistikk over skogforhold og skogressurser i Hordaland. Ressursoversikt fra Skog og Landskap $3 / 2013$.

Angelstam, P., Breuss, M., Mikusiński, G., Stenström, M., Stighäll, K. \& Thorell, D. 2002. Effects of forest structure on the presence of woodpeckers with different specialisation in a landscape history gradient in NE Poland. In: Chamberlain, D. \& Wilson, A. (Eds.), Avian Landscape Ecology. IALE, UK, pp. 25-38.

Aulen, G. 1988. Ecology and distribution history of the White-backed Woodpecker Dendrocopus leucotos in Sweden. Swedish University Agricultural Sciences, department Wildlife Ecology. Report No. 14, Uppsala, Sweden.

Byrkjedal, I. \& Kålås, J.A. 2012. Censuses of breeding birds in a South Norwegian arctic-alpine habitat three decades apart show population declines in the most common species. Ornis Norvegica 35: 43-47. 
Carlson, A. 2000. The effect of habitat loss on a deciduous forest specialist species: the White-backed Woodpecker (Dendrocopus leucotos). Forest Ecology and Management 131: 215-221.

Czeszczewik, D. 2009. Foraging behaviour of White-backed Woodpeckers Dendrocopus leucotos in a primeval forest (Bialowieza National Park, NE Poland): dependence on habitat resources and season. Acta Ornithologica 44: 109-118.

Czeszczewik, D. \& Walankiewicz, W. 2006. Logging affects the White-backed Woodpecker Dendrocopus leucotos distribution in the Bialowieza forest. Annales Zoologici Fennici. 43: 221-227.

Czeszczewik, D., Walankiewicz, W., Mitrus, C., Tumiel, T., Stanski, T., Sahel, M. \& Bednarczyk, G. 2013. Importance of dead wood resources for woodpeckers in coniferous stands of the Bialowieza Forest. Bird Conservation International 23: 414-425.

Edenius, L., Brodin, T. \& Sunesson, P. 1999. Winter behaviour of the Grey-headed Woodpecker Picus canus in relation to recent population trends in Sweden. Ornis Svecica 9: $65-74$.

Fraixedas, S., Lindén, A. \& Lehikoinen, A. 2015. Population trends of common breeding forest birds in southern Finland are consistent with trends in forest management and climate change. Ornis Fennica 92: 187-203.

Gjerde, I. \& Sætersdal, M. 2017. Muligheter for en forenklet kartlegging av MiS-livsmiljøer I kyststrøk. Nibio Rapport 3, 52.

Gjerde, I., Rolstad, J. \& Rinden, H. 1992. Hvitryggspetten på Østlandet: hekkehabitat og bestandsutvikling sett i forhold til driftsendringer i landbruket. Rapport fra Skogforsk 15/92.

Gjerde, I., Sætersdal, M. \& Blom, H.H. 2007. Complementary hotspot inventory - A method for identification of important areas for biodiversity at the forest stand level. Biological Conservation 137: 549-557.

Gjerde, I., Sætersdal, M. \& Nilsen, T. 2005. Abundance of two threatened woodpecker species in relation to the proportion of spruce plantations in native pine forests of western Norway. Biodiversity and Conservation 14: 377-393.

Granhus, A., Hylen, G. \& Nilsen, J-E.Ø. 2012. Skogen i Norge. Statistikk over skogforhold og skogressurser i Norge registrert i perioden 2005-2009. Ressursoversikt fra Skog og Landskap 03/2012.

Haavik, A. \& Dale, S. 2012. Are reserves enough? Value of protected areas for boreal forest birds in southeastern Norway. Ann. Zool. Fenn. 49: 69-80.

Hogstad, O. \& Stenberg, I. 1994. Habitat selection of a viable population of White-backed Woodpeckers Dendrocopus leucotos. Fauna Norv. Ser. C. Cinclus 17: 75-94.

Hogstad, O. \& Stenberg, I. 1997. Breeding success, nestling diet and parental care in the White-backed Woodpecker Dendrocopus leucotos. Journal für Ornithologie 138: 25-38.

Hogstad, O. \& Stenberg, I. 2005. Sexual differences in physical condition in the White-backed Woodpecker Dendrocopus leucotos in relation to habitat type and across season. Ornis Fennica 82: 26-31.

Lehikoinen, A. \& Virkkala, R. 2018. Population trends and conservation status of forest birds. Pp. 389-426 in: Mikusinski, G., Roberge, J. - M. \& Fuller, R. J. (Eds). Ecology and Conservation of Forest Birds. Cambridge University Press, Cambridge.

Lehikoinen, A., Lehikoinen, P., Linden, A. \& Laine, T. 2011. Population trend and status of the endangered Whitebacked Woodpecker Dendrocopus leucotos in Finland. Ornis Fennica 88: 195-207.

Lõhmus, A., Nellis, R., Pullerits, M. \& Leivits, M. 2016. The potential for long-term sustainability in seminatural forestry: a broad perspective based on woodpecker populations. Environmental Management 57: 558-571.

Michaelsen, T.C. 2016. Aspen Populus tremula is a key habitat for tree-dwelling bats in boreonemoral and south boreal woodlands in Norway. Scandinavian Journal of Forest Research 31: 477-483.

Mikusiński, G., Gromadzki, M. \& Chylarecki, P. 2001. Woodpeckers as indicators of forest bird diversity. Conservation Biology 15: 208-217.

Moen, A. 1999. National Atlas of Norway: Vegetation. Norwegian Mapping Authority, Hønefoss.

Privetivy, T., Adam, D. \& Vrska, T. 2018. Decay dynamics of Abies alba and Picea abies deadwood in relation to environmental conditions. Forest Ecology and Management 427: 250-259.

Program for terrestrisk naturovervåking. 2019. TOVEkstensiv overvåking av hekkefugl. Metodehefte. Versjon 2.2n, 5. februar 2019.

Remm, J. \& Lõhmus, A. 2011. Tree cavities in forests - the broad distribution pattern of a keystone structure for biodiversity. Forest Ecology and Management 262: 579-585.

Roberge, J-M. \& Angelstam, P. 2006. Indicator species among resident forest birds - a cross-regional evaluation in northern Europe. Biological Conservation 130: 134147.

Roberge, J-M., Angelstam, P. \& Villard, M-A. 2008a. Specialised woodpeckers and naturalness in hemiboreal forests - Deriving quantitative targets for conservation planning. Biological Conservation 141: 997-1012.

Roberge, J-M., Mikusinski, G. \& Svensson, S. 2008b. The white-backed woodpecker: umbrella species for forest conservation planning? Biodiversity and Conservation 17: 2479-2494.

Rolstad, J. \& Rolstad, E. 1995. Seasonal patterns in home range and habitat use of the Grey-headed Woodpecker Picus canus as influenced by the availability of food. Ornis Fennica 72: 1-13.

Rolstad, J., Løken, B. \& Rolstad, E. 2000. Habitat selection as a hierarchical spatial process: the green woodpecker at the northern edge of its distribution range. Oecologia 124: 116-129.

Rue, H., Martino, S. \& Chopin, N. 2009. Bayesian inference 
for latent Gaussian models by using integrated nested Laplace approximations. J. R. Stat. Soc. 71: 319-392.

Saari, L. \& Mikusinski, G. 1996. Population fluctuations of woodpecker species on the Baltic island of Aasla, SW Finland. Ornis Fennica 73: 168-178.

Sippola, A-L., Siitonen, J. \& Kallio, R. 1998. Amount and quality of coarse woody debris in natural and managed coniferous forests near the timberline in Finnish Lapland. Scandinavian Journal of Forest Research 13: 204-214.

Stenberg, I. 2004. Bestandsestimat og utbreiing av kvitryggspett Dendrocopos leucotos i Noreg. Ornis Norvegica 27: 94-105.

Stenberg, I. \& Hogstad, O. 1992. Habitat use and density of breeding woodpeckers in the 1990's in Møre og Romsdal county, western Norway. Fauna Norvegica Ser. C, Cinclus 15: 49-61.

Stenberg, I. \& Hogstad, O. 1995. Populasjonstetthet og økologi hos hvitryggspett og andre hakkespetter i VestNorge. Aktuelt fra Skogforsk, Rapport 10-95.

Stenberg, I. \& Hogstad, O. 2004. Sexual dimorphism in relation to winter foraging in the White-backed Woodpecker (Dendrocopus leucotos). Journal für Ornithologie 145: 321-326.

Stenberg, I. \& Stokke, P.K. 2003. Kvitryggspettens habitatval i Noreg. NOF rapportserie, Rapport nr. 2-2003.
Stighäll, K. 2015. Habitat composition and restocking for conservation of the white-backed woodpecker in Sweden. PhD-thesis. Örebro University.

Stokland, J.N. \& Larsson, K-H. 2011. Legacies from natural forest dynamics: Different effects of forest management on wood-inhabiting fungi in pine and spruce forests. Forest Ecology and Management 261: 1707-1721.

Storaunet, K.O. \& Rolstad, J. 2015. Mengde og utvikling av død ved i produktiv skog i Norge. Oppdragsrapport fra Skog og Landskap, 06/2015.

Tomter, S.M. \& Dalen, L.S. 2018. Berekraftig skogbruk i Norge. Norsk Institutt for Bioøkonomi.

Virkkala, R., Alanko, T., Laine, T. \& Tiainen, J. 1993. Population contraction of the White-backed Woodpecker Dendrocopus leucotos in Finland as a consequence of habitat alteration. Biological Conservation 66: 47-53.

Øyen, B-H. 2007. Provenienser, vekst og egenskaper for gran (Picea abies L. Karst.) på Vestlandet. Viten fra Skog og Landskap 2/2007: 13-22.

Øyen, B-H., Blom, H.H., Gjerde, I., Myking, T., Sætersdal, M. \& Thunes, K.H. 2006. Ecology, history and silviculture of Scots pine (Pinus sylvestris L.) in western Norway a literature review. Forestry 79: 319-329.

Received 21.12.2018. Accepted 26.08.2019 